\title{
Surface application of calcium-containing gels to improve quality of late-maturing peach cultivars
}

\author{
Victoria Fernández, Azahara Díaz, Álvaro Blanco and Jesús Val \\ Estación Experimental de Aula Dei (CSIC). Avda. Montañana 1005, 50059-Zaragoza \\ (Spain)
}

Running Title: Ca-containing gels and peach quality

\begin{abstract}
BACKGROUND: A strategy to supply Ca directly to fruits as tool for improving peach quality has been devised and tested under field conditions. Since peaches in the area of study (Calanda, Spain) are routinely bagged shortly after thinning, a method based on the application of Ca-gels to the fruit surface was introduced. The effect of surface treaments was assessed in terms of quality, nutrient balances and surface deposition as observed by SEM-EDX.

RESULTS: Application of Ca-containing formulations increased mesocarp and exocarp Ca concentrations, providing evidence for the penetration of $\mathrm{Ca}$ through the peach skin. Surface Ca treatments had a particular mode of deposition and in some instances, improved the shelf-life of fruits without affecting quality.

CONCLUSION: Surface treatment with Ca-gels is a viable approach to increase fruit Ca, quality and storability of bagged, peach cultivars, which should be optimised in the future.
\end{abstract}


Keywords: adjuvants; calcium formulations; fruit quality; fruit surface; Prunus persica L. Batsch; surface treatments

\section{INTRODUCTION}

Late maturing peaches (Prunus persica L. Batsch.) are becoming increasingly important for the fruit industry, since in recent years the market demand for such commodity is raising significantly. With regard to the Spanish market, consumers have a clear preference for this type of late season cultivars, which renders the production of such fruits highly-profitable as compared to other horticultural crops.

Late season peaches are a speciality of the Calanda area, in the Ebro Valley (Aragón, Spain), where fruits are harvested up to mid-October. The current increase in consumer demand and the need to extend the marketing season implies that fruits have to be cold-stored for longer periods. Fruit storage for longer times is in turn raising the incidence of physiological disorders that deteriorate quality, which ultimately translates into losses for the peach industry.

Peaches are highly perishable fruits that may deteriorate quickly when stored at room temperature. Low temperature during storage significantly extends fruit market life ${ }^{1}$. In the case of high-cash Calanda peaches, the great increase in consumer demand has led to storing fruits at $0^{\circ} \mathrm{C}$ with the aim of both delaying fruit senescence (extending shelflife) and avoiding other chilling-related disorders such as e.g., 'internal breakdown' that may occur between $2.2^{\circ}$ and $7.8^{\circ} \mathrm{C} .^{2}$

The main disorder affecting late season cultivars grown in Northeast Spain is the “vitrescent dark spot”, a peach disorder which has been recently characterized.,4 Briefly, injured fruit mesocarp areas become translucent and turn dark, while no external symptoms can be observed until long after harvest. The vitrescent dark spot 
observed in peaches is somehow similar to bitter pit, lenticel blotch pit and similar physiological disorders described for apples and other horticultural species, which have been related to Ca alterations in fruit metabolism. ${ }^{5,6}$ In apple, Ca sprays to increase fruit Ca availability have long been recommended to prevent the development of bitter pit and other disorders. ${ }^{7,8}$ The limited mobility of Ca in the plant makes it necessary that Ca is directly applied to the fruits since apparently $\mathrm{Ca}$ is not easily re-translocated to such organs after foliar treatment. ${ }^{9}$ On the other hand, Ca applications have been proposed to be useful for enhancing peach quality, ${ }^{10,11}$ particularly with regard to extending the relatively short shelf-life of these fruits.

Fruit and leaf treatment with Ca sprays is a widely-used strategy to avoid the incidence of physiological disorders in fruits. ${ }^{12,13}$ The efficacy of Ca treatments supplied to leaves and fruits may be highly variable and currently, many factors related to the penetration and distribution of surface-applied Ca remain unclear. ${ }^{14}$ The low mobility of $\mathrm{Ca}$ in the plant poses serious problems to improve its distribution to the fruit via $\mathrm{Ca}$ application to the root system. Therefore treatment of aerial plants with Ca sprays, is recommended and applied in many fruit production areas of the world either as routine treatments to prevent the occurrence of localised $\mathrm{Ca}$ deficiencies in the fruit or to improve its quality. ${ }^{15,16}$ However, response to foliar Ca sprays may be variable and fruit growers often obtain inconsistent results after treatment. ${ }^{17}$

Penetration of the fruit surface by a nutrient solution may take place via the cuticle, cuticular cracks and imperfections, through stomata, lenticels and also via trichomes or specialised epidermal cells. While the significance of the stomatal pathway on the absorption of foliar sprays has been a matter of controversy for many years, recent evidence shows that it can largely contribute to the penetration process. ${ }^{18}$ In this regard, there is not much information available on the potential contribution of stomata, 
lenticels and trichomes present in the skin of fruits to the process of penetration of surface-applied chemicals.

Most research efforts in the last 60 years were devoted to investigate the diffusion of substances through the plant cuticle. ${ }^{19}$ Such studies enabled the development of the "diffusion-dissolution model" for the cuticular penetration of apolar, lipophilic compounds. ${ }^{20}$ On the other hand, the mechanisms of penetration of hydrophilic solutes through the cuticle are currently not fully understood, ${ }^{19}$ and the existence of "aqueous pores” as a parallel diffusion pathway has been hypothesised. ${ }^{21}$

Since the last decade, there is growing interest in the development of thermoplastic materials from biodegradable polymers, particularly those derived from renewable resources. $^{22,23}$ Bio-based packaging is defined as packaging containing raw materials originating from agricultural sources, i.e. produced from renewable, biological raw materials such as starch and bio-derived monomers. Tara gum is used in the agro-food industry as a thickening agent and a stabilizer. It is obtained by grinding the endosperm of the seeds of the tree Caesalpinia spinosa (Fam. Leguminosae). Such gum is composed of high molecular weight polysaccharides, chiefly galactomannans and has a ratio of 3:1 mannose to galactose. This additive meets the scientific standards required for classification as a GRAS food ingredient. ${ }^{24,} 25$ In 1986, the Joint FAO/WHO Expert Committee on Food Additives (JECFA) evaluated the safety of Tara gum (E417) and classified it as a food additive within the bounds of Good Manufacturing Practice (GMP).

Historically, one of the main features of growing Calanda peaches is that fruits are individually bagged to avoid damage caused by the Mediterranean fly (Ceratitis capitata Wied.). This practice is generally implemented shortly after fruit thinning and fruits in grown such way are marketed as top quality and agrochemical-free. However, 
the presence of the bag may limit the absorption of Ca sprays, thereby justifying the development of new fertilisation methods to improve fruit Ca status. In this study, the performance of surface-applied Ca formulations containing bio-based gels applied prior to bagging, was assessed as a strategy to improve the quality, nutrient balance and storability of Calanda peaches.

\section{EXPERIMENTAL}

\section{Plant material and experimental lay-out}

Experiments were carried out in 2 commercial orchards located in Puigmoreno and Caspe (Zaragoza, Spain) during the summer season of 2007 and 2008.

In a preliminary experiment carried out in 2007, homogeneous, mature cv. Jesca trees were selected, and 50 fruits per tree were surface-treated with a gel containing 2 different Ca-containing compounds. The resulting 6 different treatments were organised following a completely randomized block, with 4 replications. Surface treatments were applied on August $14^{\text {th }}$, 2007 and fruits were immediately bagged thereafter. Treated fruits were collected at the time when all fruits in the orchard were harvested for commercial purposes (October $9^{\text {th }}$ ) and quality traits were subsequently measured under laboratory conditions at harvest and after 43 and 69 days.

In 2008, at the time of bagging (June $23^{\text {rd }}$ ) the same treatments were applied to mature uniform 'Calrico' peach trees grown in “Finca de Demostración de Nuevas Tecnologías en Fruticultura, Mas de la Punta”, Caspe, Spain. Again, treatments were applied following a completely randomized block design (4 replications). At harvest (September $17^{\text {th }}$ ), fruits were collected and random samples were either taken for quality assessment or kept under cold storage $\left(0^{\circ}-0.5^{\circ} \mathrm{C}\right)$ to evaluate the quality traits at harvest and 20 days, respectively. After 49 days cold storage, fruits were classified 
according to a browning scale and the external quality appearance was estimated as described below.

\section{Treatment application}

Gels were prepared by adding $0,0.12$ or $0.25 \mathrm{~mol} \mathrm{~L}^{-1}$ Ca (i.e., $0,0.5$ or $1 \% \mathrm{Ca}$ ) supplied either as $\mathrm{CaCl}_{2} 6 \mathrm{H}_{2} \mathrm{O}$ (Panreac, Spain) or Ca-propionate (Chemworld S.A., Spain) to a $10 \mathrm{~g} \mathrm{~L}^{-1}$ Tara gum (TG, Chemworld S.A., Spain) solution. Treatment formulations were uniformly applied over the entire fruit surface by hand-smearing. In average, $2.3 \mathrm{~g}$ of the gel were applied to approximately $50 \mathrm{~mm}$ diameter fruits. Peaches were immediately bagged after treatment, using the standard paper bags commercially available for this purpose (Cooperativa Agrícola San Lorenzo, Maella, Spain).

\section{Fruit quality evaluation}

In each experiment, samples of 10 random fruits were collected at harvest, and at different dates along the cold storage period. Each individual fruit was weighed and its diameter recorded. Quality at the time of harvest and after cold storage was assessed in 2 opposite sides of the same fruit by measuring: flesh firmness (using an Effegi penetrometer fitted with an 8-mm tip, Bertuzzi, Brugherio, Italy), total soluble solids content (SSC, determined with an ATAGO PR-101 digital refractometer, Atago Co., Tokyo, Japan), titriable acidity (TA) and L*a*b* colour (using a CR-200 chromometer, Minolta Co., Osaka, Japan). In 2008, yield quality (November $5^{\text {th }}$ ) was rated into 3 classes according to fruit appearance. Fruits were classified as: (i) excellent, when they were of extremely good quality, (ii) acceptable, when quality was not superb but remained good enough for marketing, and (iii) unmarketable, when fruit quality was poor. Data are presented as the percentage of each class over the total number of fruits 
(57 \pm 8 fruits per treatment). In addition, chilling injury symptoms were evaluated according to the browning scale proposed by Kader and Chordas ${ }^{26}$ in 10 fruits per treatment on $5^{\text {th }}$ November, 2008.

Fruit tissue $\mathrm{K}, \mathrm{Mg}$ and $\mathrm{Ca}$ concentrations were analysed at the time of harvest. For mineral element determination, 5 fruits per sample were randomly selected and carefully washed, and 1-cm sections excised from the equator of the fruit were collected. From these areas, the exocarp was carefully separated from the mesocarp, and tissues were subsequently prepared for analysis. Peels were finely cut ( $<1 \mathrm{~mm}$ pieces), and $0.5 \mathrm{~g}$ were taken for mineral element determination. Fruit mesocarps were cut into small pieces and $2 \mathrm{~g}$ of tissue were analysed per sample. Tissues were consequently wet-digested using $10 \mathrm{~mL} \mathrm{HNO}_{3}$ and $2 \mathrm{~mL} \mathrm{H}_{2} \mathrm{O}_{2}$ on a hot plate. Once the samples were dry, they were dissolved in $10 \mathrm{~mL} \mathrm{HCl}$ and $15 \mathrm{~mL} \mathrm{H}_{2} \mathrm{O}$ were added. Calcium and $\mathrm{Mg}$ were measured by Atomic Absorption Spectroscopy and K was determined by Flame Emission Spectroscopy (Thermo Scientific iCE 3300 Atomic Absorption/Emission Spectrophotometer, Cambridge, UK). Data were expressed in terms of fruit fresh weight $(\mathrm{FW})$.

Data were analyzed by ANOVA as a linear general model, and when significant, means were separated by the Duncan's multiple range test suited for unplanned pair comparisons, ${ }^{27}$ using the statistical programme SPSS 15.0.

\section{Scanning Electron Microscopy}

In 2008, samples of peach exocarps were excised and prepared for Scanning Electron Microscopy observation (SEM, Hitachi S-3400 N, equipped with a Si(Li) EnergyDispersive X-ray Spectroscopy detector (EDX), Röntec XFlash; acceleration potential $15 \mathrm{kV}$ and working distance 10 to $11 \mathrm{~mm}$ ). Probes were taken from fruits collected at 
the time of harvest and were either directly examined or observed after spraying to run off with distilled water or immersion in distilled water for 5 min. The composition of the particles deposited on the peach surface was analysed by SEM-EDX.

\section{RESULTS}

The application of gum-based formulations to peaches did not induce any phytotoxic effects on the fruit in any of trials performed.

Results recorded in 2007 showed that the Ca concentration in the fruit mesocarp increased after application of Ca gels as compared to that of untreated or pure TGtreated fruits (Fig. 1). Mesocarp Ca increases were measured after application of $\mathrm{CaCl}_{2}$ and Ca-propionate formulations, the increment being higher in association with treatment with the highest Ca rate (i.e., $0.25 \mathrm{~mol} \mathrm{~L}^{-1}$ ). Similarly, fruits treated with Capropionate-containing gums had higher exocarp Ca concentrations than those treated with $\mathrm{CaCl}_{2}$ (Fig. 2). In general, $\mathrm{Mg}$ and $\mathrm{K}$ tissue concentrations were not affected by the treatments with the exception of Mg mesocarp concentrations, which increased in fruits treated with $0.25 \mathrm{~mol} \mathrm{~L}^{-1} \mathrm{Ca}$.

Evaluation of quality traits at the time of harvest showed no differences between Catreated fruits and those treated with plain TG or left untreated (Table 1). For SSC, levels tended to be higher in fruits treated with $0.25 \mathrm{~mol} \mathrm{~L}^{-1} \mathrm{Ca}$, although they were not significantly different.

Fruits were stored under cold conditions for approximately 3 months and samples were randomly collected for quality evaluation. Data recorded after 43 days storage indicated no significant quality changes (Table 2), however, after more than 2 months, most of the fruits treated with $0.25 \mathrm{~mol} \mathrm{~L}^{-1} \mathrm{CaCl}_{2}$ formulations were damaged either by biotic or abiotic factors (i.e., having signs of dehydration, internal breakdown, fungal 
growth or chilling injury), and were discarded for quality evaluation. Of the quality traits analysed, only mesocarp firmness decreased after the application Ca-containing formulations.

At harvest $\left(17^{\text {th }}\right.$ September, 2008), significant Ca increases were measured in the mesocarp and exocarp of fruits treated with $0.25 \mathrm{~mol} \mathrm{~L}^{-1}$ Ca-containing formulations (Figs. 3 and 4). No effects of the treatments regarding Mg mesocarp and exocarp concentrations, but increasing $\mathrm{K}$ levels were detected in the mesocarp of fruits treated with Ca-propionate. Evaluation of quality traits at this date showed that the SSC of the fruits varied according to the treatment applied, while again no significant changes between Ca-treated and untreated fruits were observed for the rest of parameters evaluated (Table 3).

Unlike in the first experimental season, a sample of fruits was stored at $0^{\circ} \mathrm{C}$. After 3 weeks under cold storage, the SSC of the mesocarp was the only trait affected by the Ca treatments (Table 3). Fruits treated with 0.12 or $0.25 \mathrm{~mol} \mathrm{~L}^{-1}$ Ca-propionate had the highest SSC levels, while fruits supplied with $0.25 \mathrm{M} \mathrm{CaCl}_{2}$ had lower SSC values.

Seven weeks after harvest, the state of fruits stored under cold conditions was evaluated in terms of the proportion of fruits with 3 different degrees of commercial quality (Fig. 5). The results show that fruits treated with $0.25 \mathrm{~mol} \mathrm{~L}^{-1} \mathrm{CaCl}_{2}$ gels had the greatest proportion of unmarketable fruits, while those treated with $0.12 \mathrm{~mol} \mathrm{~L}^{-1} \mathrm{Ca}$ had the lowest rate of unmarketable fruits and the greatest proportion of excellent quality peaches.

The development of chilling injuries after 7 weeks cold storage was evaluated by applying a browning scale (Figure 6). Fruits treated with $0.25 \mathrm{M} \mathrm{CaCl}_{2}$ had the highest degree of injury, while those treated with $0.12 \mathrm{~mol} \mathrm{~L}^{-1} \mathrm{CaCl}_{2}$ presented a lower degree of damage associated with cold storage conditions. 
Micrographs of the surface of peaches subjected to the different treatments revealed a different pattern of deposition of the remains of the TG-based formulations, 3.5 months after application (Figure 7). The surface of untreated peaches (Fig. 7A) has hairs but apparently to a lower density as compared to the TG-treated peach skin (Fig. 7B), likely due to a lower rate of hairs falling off the fruit, since they were stuck to each other by the gum. While Ca-propionate treatments led to the occurrence of Ca deposits on the surface as analysed by SEM-EDX (Figs.7E,F), Ca was not observed to precipitate significantly in the surface of $\mathrm{CaCl}_{2}-\mathrm{TG}$ treated peaches (Figs. C,D), indicating the better solubility of this inorganic salt in the matrix used as compared to Ca-propionate. The most striking feature observed was the appearance of peach surfaces treated with $0.12 \mathrm{~mol} \mathrm{~L}^{-1} \mathrm{CaCl}_{2}-\mathrm{TG}$, as shown more in detail in the close up (x400; Fig. 7C). At the time of treatment a uniform gel layer formed, which was subsequently perforated over the growing season due to hair growth, giving it the appearance of a network at the end of the experimental period. The results relating to $\mathrm{CaCl}_{2}-\mathrm{TG}$ treatments suggest that Ca was able to interact with the TG molecules when applied at a

concentration of $0.12 \mathrm{~mol} \mathrm{~L}^{-1}$, giving rise to a polymer with different physical-chemical characteristics as compared to the $1 \mathrm{~g} \mathrm{~L}^{-1} \mathrm{TG}$ solution alone.

Washing fruit surfaces either by distilled- $\mathrm{H}_{2} \mathrm{O}$ spraying to run-off or via immersion in distilled $\mathrm{H}_{2} \mathrm{O}$, enabled removing the surface-applied formulation without damaging the peach skin (micrographs not shown).

\section{DISCUSSION}

Fruit Ca application to aerial plant parts as a means to prevent the occurrence of physiological disorders is becoming a standard cultural practice in many fruit producing areas or the world. The high economic returns associated with fruit crops, and 
particularly, with bagged Calanda peaches, justify the search for target-oriented strategies to effectively improve the Ca status of fruits over the growing season. The characteristic feature of the production of late-ripening cvs. in the area of Aragón (Spain), is that peaches remain in bags for most of the fruit growth and development period, a method which physically limits the exposure of fruits to pests and agrochemicals and also reduces the efficiency of canopy nutrient sprays. Thereby, with the aim of increasing the Ca availability of bagged peaches, a novel strategy based on a single surface application of a Ca-containing gel was devised and tested under field conditions, with successful results in terms of fruit Ca increases and postharvest shelflife. Gel-based $0.12 \mathrm{~mol} \mathrm{~L}^{-1}$ Ca treatments applied to the surface of Calanda peaches prior to bagging did significantly improve the storability of the fruits without inducing detrimental quality effects. Calcium treatment is often applied to improve fruit firmness, and quality traits although the relationship between $\mathrm{Ca}$ and firmness is not clearly understood so far. ${ }^{28}$

While the application of multiple in-season Ca sprays to prevent the development of Ca-related physiological disorders has been shown to be beneficial in many studies (e.g. ${ }^{7}, 15,29$ ) there is conflicting evidence regarding their efficacy to increase the Ca status in some fruit crops such as apple. ${ }^{17}$ Given the low mobility of Ca in the plant, the success of the treatment relies on adequate absorption of Ca by the fruit itself. ${ }^{30}$ Prior to the beginning of the trial, large coefficients of variation for $\mathrm{Ca}$ concentrations in 'Calrico' peaches were determined, showing the large variability of Ca distribution between fruits, as described for apple. ${ }^{30}$ Furthermore, surface Ca application trials developed with several fruit crops often led to inconsistent results, mainly due to the reduced penetrability of the fruit surface of some fruits species, as observed in apple. 17,31 
As the outermost layer of fruit epidermis, the cuticle constitutes the main permeability barrier between the mesocarp and the surrounding environment, limiting the 2-way exchange of gases and solutes, and also protecting it from mechanical and biotic damage. ${ }^{32}$ Thereby, the characteristics of the fruit surface and composition and structure of the cuticular components will determine the contact properties and permeability to surface-applied solutes. While there is no information available regarding the permeability of the peach surface, preliminary trials developed by our Group (unpublished data) indicated that application of in-season Ca sprays to fruits increased the Ca budget of the peach skin and pulp, in contrast to the results obtained for apple Ca sprays where no significant effects were observed at the time of harvest. ${ }^{17}$

Due to the fact that in our area, late season peach cvs. are grown in bags and that there is an increasing occurrence of fruit injuries resembling those caused by Ca-related disorders $^{33}$, we developed a Ca formulation suitable for application to the peach skin prior to bagging and containing additives capable of enhancing the penetration and distribution of $\mathrm{Ca}$ into the fruit. Several authors stressed the importance of using formulation adjuvants to improve the performance of surface-applied agrochemicals and Ca treatments. ${ }^{19,34,35}$ Thereby, a biodegradable compound of natural origin ${ }^{23}$ with humectant properties (solutions remained wet for several hours after treatment) and capable of sticking to the peach surface forming a layer, was selected as a matrix for supplying $\mathrm{Ca}$ to the fruit. The Ca concentrations employed were in the same range as the ones tested by e.g., Schmizt-Eiberger et al., ${ }^{35}$ or Harker and Ferguson, ${ }^{32}$ but were well above the values evaluated in some Ca penetration cuticular studies. ${ }^{36,37}$ According to our experience with Ca sprays, high but not phytotoxic Ca concentrations must be supplied to fruits and leaves under the dry and warm environmental conditions prevailing in our area, which obviously do not favour the penetration of surface-applied 
treatments at certain times of the day. An inorganic salt of lower molecular weight and a point of deliquescence of $55 \%\left(\mathrm{POD}, \mathrm{CaCl}_{2} 6 \mathrm{H}_{2} \mathrm{O}\right)$ was tested versus the effect of Capropionate (POD around 95\%), ${ }^{37}$ due to the antifungal properties of the latter compound. According to Schönherr, ${ }^{37}$ Gum guar $\left(5 \mathrm{~g} \mathrm{~L}^{-1}\right)$ greatly slowed the penetration of $45 \mathrm{mmol} \mathrm{L}^{-1} \mathrm{CaCl}_{2}$ through pear leaf cuticles even at 90\% relative humidity, thereby he recommended it to be excluded as additive for foliar sprays. However, we observed that Tara gum changed the physical-chemical properties of the Ca solutions providing some sort of a slow-release effect, probably related to solution re-wetting, as derived from the subsequent fruit $\mathrm{Ca}$ increases measured after harvest. While Ca deposits in association with Ca-propionate treatment were observed by SEM (Fig. 7), no Ca particles were significantly noticed after treatment with $\mathrm{CaCl}_{2}$ as determined by EDX detection (data not shown). Treatment remains after application of $0.12 \mathrm{~mol} \mathrm{~L}^{-1} \mathrm{CaCl}_{2}$ were observed to look like a network formed after the action of hairs growing against and perforating the layer formed by the gel applied to the peach skin with no presence of isolated precipitates. Since the rest of treatments did not give rise to the occurrence of such grid (hardy seen in $0.25 \mathrm{~mol} \mathrm{~L}^{-1} \mathrm{CaCl}_{2}$-GT treated peaches), it is concluded that Ca at a proportion of $0.12 \mathrm{~mol} \mathrm{~L}^{-1}$, interacted with the TG molecules (applied at $10 \mathrm{~g} \mathrm{~L}^{-1}$ ), giving rise to a new polymer with different physical-chemical properties. We cannot exclude the possibility that the TG molecules penetrated into the fruit surface but this appears a priori unlikely due to their large molecular size, as suggested by Schönherr. ${ }^{37}$

The characteristics of the resulting $0.12 \mathrm{~mol} \mathrm{~L}^{-1}$ Ca-polymer should be elucidated and the potential of GT-based solutions to provide surface agrochemical treatments with slow-release properties must be further explored in the future.

\section{CONCLUSIONS}


A novel strategy to supply Ca to late season peaches prior to bagging was devised and tested under field conditions. Tara gum, an additive commonly used in the food industry with hygroscopic and thickening properties was used at a rate of $1 \mathrm{~g} \mathrm{~L}^{-1}$ in combination with $\mathrm{CaCl}_{2}$ and Ca-propionate (0.12 and $\left.0.25 \mathrm{~mol} \mathrm{~L}^{-1} \mathrm{Ca}\right)$. Calcium-containing surface treatments successfully increased the Ca budget of fruits at the time of harvest, providing evidence for the penetration and distribution of $\mathrm{Ca}$ applied as a gel. In addition, surface treatment with $0.12 \mathrm{~mol} \mathrm{~L}^{-1} \mathrm{CaCl}_{2}$-GT gave rise to a polymer with different physical-chemical characteristics and some sort of slow-release properties as compared to the other treatments. The formulation and method of application proposed in this study should be further optimised in future attempts, but proves a promising and feasible strategy for providing additional Ca to late season peach varieties, following the standard cultivation practices employed in the area of Aragón (Spain).

\section{ACKNOWLEDGEMENTS}

Work financed by DGA (PM005/2006) and INIA, PET2007-09-C5, co-financed by the European Social Fund. The authors acknowledge Mr. J.L. Espada (CTA - DGA) for technical and scientific support, and "Cooperativa San Miguel of Puigmoreno", and the Administration Council of the "Finca de Demostración de Nuevas Tecnologías en Fruticultura”, Caspe, Spain, for providing orchards and management for experimental purposes. Work of Victoria Fernández is supported by a "Juan de la Cierva”-MEC postdoctoral contract, co-financed by the European Social Fund.

\section{REFERENCES}

1. Crisosto $\mathrm{CH}$, Mitchell FG and Ju Z, Susceptibility to chilling injury of peach, nectarine, and plum cultivars grown in California. HortSci. 34 (1999). 
2. Crisosto $\mathrm{CH}$, How Do we increase peach consumption? Acta Hort. 592:601-605 (2002).

3. Val J, Calidad del melocotón de Aragón. Estudio de calciopatías (mancha vitrescente) por métodos convencionales, espectroscópicos y diagnóstico precoz. Nutrifitos 171:87-98 (2007).

4. Fernández V, Blanco A and Val J, Preliminary characterisation of "vitrescent dark spot”: a peach physiological disorder of increasing occurrence in late ripening cultivars. Acta Hort. (in press) (2009).

5. Val J, Gracia MA, Monge E and Blanco A, Visual detection of calcium by GBHA staining in bitter pit affected apples. Food Sci. Tech. Int. 14:315-319 (2008).

6. Val J, Blanco A, Monge E and Pérez M, Polyphenoloxidase isozymes in bitter pit affected apple tissues either natural or locally induced by ammonium oxalate injections. Acta Hort. (in press) (2009).

7. Ferguson IB and Watkins CB, Bitter pit in apple fruit. Hort. Rev. 11:289-355 (1989).

8. Saure MC, Calcium translocation to fleshy fruit: its mechanism and endogenous control. Sci. Hortic. 105:65-89 (2005).

9. Hill J, The remobilization of nutrients from leaves. J. Plant Nutr. 2:407-444 (1980).

10. Poovaiah BW, Glenn GM and Reddy ASN, Calcium and fruit softening: physiology and biochemistry. Hort. Rev. 10:107-152 (1988).

11. Serrano M, Martínez-Romero D, Castillo S, Guillén F and Valero D, Effect of preharvest sprays containing calcium, magnesium and titanium on the quality of peaches and nectarines at harvest and during postharvest storage. J. Sci. Food Agric. 84:1270-1276 (2004). 
12. Schlegel TK and Schönherr J, Stage of development affects penetration of calcium chloride into apple fruits. J. Plant Nutr. Soil Sci. 165:738-745 (2002).

13. Kraemer T, Hunsche M and Noga GJ, Cuticular calcium penetration is directly related to the area covered by calcium within droplet spread area. Sci. Hortic. 120:201206 (2009).

14. Bai RQ, Schlegel TK, J. S and Masinde PW, The effects of foliar applied $\mathrm{CaCl}_{2}$. $2 \mathrm{H}_{2} \mathrm{O}, \mathrm{Ca}(\mathrm{OH})_{2}$ and $\mathrm{K}_{2} \mathrm{CO}_{3}$ combined with the surfactants Glucopon and Plantacare on gas exchange of 1 year old apple (Malus domestica Borkh.) and broad bean (Vicia faba L.) leaves. Sci. Hortic. 116:52-57 (2008).

15. Manganaris GA, Vasilakakis M, Mignani I, Diamantidis G and Tzavella-Klonari $\mathrm{K}$, The effect of preharvest calcium sprays on quality attributes, physicochemical aspects of cell wall components and susceptibility to brown rot of peach fruits (Prunus persica L. cv. Andross). Sci. Hortic. 107:43-50 (2005).

16. Manganaris GA, Vasilakakis M, Mignani I, Diamantidis G and Tzavella-Klonari $\mathrm{K}$, Effect of in-season calcium applications on cell wall physicochemical properties of nectarine fruit (Prunus persica var. nectarine Ait. Maxim) after harvest or cold storage. J. Food Sci. Agric. 86:2597-2602 (2006).

17. Val J, Monge E, Risco D and Blanco A, Effect of pre-harvest calcium sprays on calcium concentrations in the skin and flesh of apples. J. Plant Nutr. 31:1889-1905 (2008).

18. Eichert T, Kurtz A, Steiner U and Goldbach HE, Size exclusion limits and lateral heterogeneity of the stomatal foliar uptake pathway for aqueous solutes and water-suspended nanoparticles. Physiol. Plant. 134:151-160 (2008). 
19. Fernández V and Eichert T, Uptake of hydrophilic solutes through plant leaves: current state of knowledge and perspectives of foliar fertilization. Crit. Rev. Plant Sci. 28:36-68 (2009).

20. Riederer M and Friedmann A, Transport of lipophilic non-electrolytes across the cuticle, in Biology of the Plant Cuticle, ed. by M. R and Müller C. Blackwell Publishing, Oxford, UK, pp 250-279 (2006).

21. Schönherr J, Characterization of aqueous pores in plant cuticles and permeation of ionic solutes. J. exp. Bot. 57:2471-2491 (2006).

22. Paes SS, Yakimets I and Mitchell JR, Influence of gelatinization process on functional properties of cassava starch films. Food Hydrocolloids 22:787-797 (2008).

23. Cerqueira MA, Pinheiro AC, Souza BWS, Lima AMP, Ribeiro C, Miranda C, Teixeira JA, Moreira RA, Coimbra MA, M. Pilar Gonçalves and Vicente AA, Extraction, purification and characterization of galactomannans from non-traditional sources. Carbohydr. Polym. 75:408-414 (2009).

24. Borzelleca JF, Ladu BN, Senti FR and Egle JL, Evaluation of the safety of tara gum as a food ingredient: A review of the literature. Int. J. Toxic. 12:81-89 (1993).

25. Belitz H-D and Grosch W, Food chemistry. Springer, Berlin, pp. 292-293 (1999).

26. Kader AA and Chordas A, Evaluating the browning potential of peaches. California Agric. 38:14-15 (1984).

27. Gomez KA and Gomez AA, Statistical procedures for agricultural research. John Wiley \& Sons, New York, pp. 187-240 (1984).

28. Huxham M, Jarvis MC, Shakespeare L, Dover CJ, Johnson D, Knox JP and Seymour GB, Electron-energy-loss spectroscopic imaging of calcium and nitrogen in the cell walls of apple fruits. Planta 208:438-443 (1999). 
29. van Goor BJ, Penetration of surface-applied 4 Ca into apple fruit. J. Hort. Sci. 48:261-270 (1973).

30. Perring MA and Wilkinson BG, The mineral composition of apples. IV.- The radial distribution of chemical constituents in apples, and its significance in sampling for analysis. J. Sci. Food Agric. 16:535-541 (1965).

31. Perring MA, Incidence of bitter pit in relation to the calcium content of apples: Problems and paradoxes, a review. J. Sci. Food Agric. 37:591-606 (1986).

32. Harker FR and Ferguson IB, Transport of calcium across cuticles isolated from apple fruit. Sci. Hortic. 36:205-217 (1988).

33. Val J, Monge E, Blanco A and Espada JL, The effects of Ca applications on peach fruit mineral content and quality. Acta Hort. (in press) (2009).

34. Harker FR and Ferguson IB, Effects of surfactants on calcium penetration of cuticles isolated from apple fruit. Sci. Hortic. 46:225-233 (1991).

35. Schmitz-Eiberger MA, Haefs R and Noga GJ, Enhancing biological efficacy and rainfastness of foliar applied calcium chloride solutions by addition of rapeseedoil surfactants. J. Plant Nutr. Soil Sci. 165:634-639 (2002).

36. Schönherr J, Calcium chloride penetrates plant cuticles via aqueous pores. Planta 212:112-118 (2000).

37. Schönherr J, Cuticular penetration of calcium salts: effects of humidity, anions, and adjuvants. J. Plant Nutr. Soil Sci. 164:225-231 (2001). 


\section{Figures:}

Figure 1. Effect of different concentrations of Ca (0, 0.12 and $\left.0.25 \mathrm{~mol} \mathrm{~L}^{-1}\right)$ from different sources ( $\mathrm{CaCl}_{2}$ or Ca propionate) applied to 'Jesca' fruits on the concentration of $\mathrm{Ca}, \mathrm{Mg}$ and $\mathrm{K}$ elements in the fruit mesocarp at harvest, and compared to an untreated control (C). Vertical bars are means \pm SE; values with the same letter are not significantly different at $P<0.05$ (Duncan's multiple range test).

Figure 2. Effect of different concentrations of Ca $\left(0,0.12\right.$ and $\left.0.25 \mathrm{~mol} \mathrm{~L}^{-1}\right)$ from two different sources $\left(\mathrm{CaCl}_{2}\right.$ or $\mathrm{Ca}$ propionate) applied to 'Jesca' peaches, on the concentration of $\mathrm{Ca}, \mathrm{Mg}$ and $\mathrm{K}$ elements at harvest in the fruit exocarp, and compared to an untreated control $(C)$. Vertical bars are means \pm SE; values with the same letter are not significantly different at $P<0.05$ (Duncan's multiple range test).

Figure 3. Concentrations at harvest of $\mathrm{Ca}, \mathrm{Mg}$, and $\mathrm{K}$ in the mesocarp of 'Calrico' peaches treated with Tara gum containing different concentrations of Ca $(0,0.12$ and $0.25 \mathrm{~mol} \mathrm{~L}^{-1}$ ) from $\mathrm{CaCl}_{2}$ or Ca-propionate. Vertical bars are means $\pm \mathrm{SE}$; values with the same letter are not significantly different at $P<0.05$ (Duncan's multiple range test).

Figure 4. Concentrations at harvest of $\mathrm{Ca}, \mathrm{Mg}$, and $\mathrm{K}$ in the exocarp of 'Calrico' peaches treated with Tara gum containing different concentrations of Ca $(0,0.12$ and

$0.25 \mathrm{~mol} \mathrm{~L}^{-1}$ ) from $\mathrm{CaCl}_{2}$ or Ca-propionate. Vertical bars are means $\pm \mathrm{SE}$; values with the same letter are not significantly different at $P<0.05$ (Duncan's multiple range test). 
Figure 5. Proportion of peaches according to three quality categories (excellent, acceptable for marketing and unmarketable), that have been subjected to the different Ca treatments, and recorded on 5 November, after 6 weeks under cold storage conditions. (Data collected over $57 \pm 8$ fruits per treatment)

Figure 6. Browning scale, recorded after 6 weeks of cold storage, applied to 'Calrico' peaches treated with Ca-containing Tara gum at different concentrations (0, 0.12 and 0.25 mol L ${ }^{-1} \mathrm{Ca}$ ), prepared from two sources: $\mathrm{CaCl}_{2}$ or Ca-propionate, and compared to untreated fruits (C). Bars are means \pm SE of 10 replicates.

Figure 7. SEM micrographs of unwashed peach surfaces 3 months after application of TG-based treatments (observed at $\mathrm{x} 100$, close up in $\mathrm{C}$ taken at $\mathrm{x} 400$ ). Images correspond to the surface of: A) untreated, B) plain $10 \mathrm{~g} \mathrm{~L}^{-1} \mathrm{TG}$ treated, C) $0.12 \mathrm{~mol} \mathrm{~L}^{-1}$ $\mathrm{CaCl}_{2}$-TG treated, D) $0.25 \mathrm{~mol} \mathrm{~L}^{-1} \mathrm{CaCl}_{2}$-TG treated, E) $0.12 \mathrm{~mol} \mathrm{~L}^{-1}$ Ca-propionate-TG treated and F) $0.25 \mathrm{~mol} \mathrm{~L}^{-1}$ Ca-propionate-TG treated. 
Table 1. Fruit quality traits at harvest of 'Jesca' peaches treated with TG-based formulations $\pm 0,0.25$ or $0.12 \mathrm{~mol} \mathrm{~L}^{-1} \mathrm{Ca} \mathrm{supplied} \mathrm{as} \mathrm{CaCl}_{2}$ or Ca-propionate (Ca-prop.).

\begin{tabular}{lcccccccc}
\hline Ca treatments & $\begin{array}{c}\text { Diameter } \\
(\mathrm{mm})\end{array}$ & $\begin{array}{c}\text { Fruit weight } \\
(\mathrm{g})\end{array}$ & $\begin{array}{c}\text { Flesh firmness } \\
(\mathrm{N})\end{array}$ & $\begin{array}{c}\text { SSC } \\
\left({ }^{\circ} \mathrm{Brix}\right)\end{array}$ & \multicolumn{2}{c}{ TA } & \multicolumn{3}{c}{ Chromaticity values } \\
& $\left(\mathrm{mg} \mathrm{L}^{-1}\right)$ & $\mathrm{L}$ & $\mathrm{a}^{*}$ & $\mathrm{~b}^{*}$ \\
\hline Control (untreated) & $74.2 \pm 0.1$ & $220.8 \pm 5.2$ & $54.2 \pm 0.9$ & $12.5 \pm 0.4$ & $5.45 \pm 0.27$ & $71.4 \pm 1.2$ & $1.12 \pm 0.32$ & $46.3 \pm 0.9$ \\
Plain TG & $75.3 \pm 0.3$ & $215.0 \pm 4.8$ & $52.2 \pm 0.8$ & $11.7 \pm 0.2$ & $5.30 \pm 0.18$ & $70.9 \pm 0.4$ & $0.10 \pm 0.66$ & $46.0 \pm 0.6$ \\
$0.12 \mathrm{Ca}\left(\mathrm{CaCl}_{2}\right)$ & $77.0 \pm 2.4$ & $224.4 \pm 15.9$ & $46.4 \pm 5.3$ & $12.0 \pm 0.5$ & $5.52 \pm 0.31$ & $70.7 \pm 0.7$ & $-1.19 \pm 1.21$ & $45.5 \pm 0.7$ \\
$0.25 \mathrm{Ca}\left(\mathrm{CaCl}_{2}\right)$ & $73.0 \pm 2.7$ & $195.7 \pm 18.3$ & $41.0 \pm 7.7$ & $13.2 \pm 0.2$ & $5.77 \pm 0.41$ & $70.3 \pm 1.0$ & $-0.27 \pm 1.41$ & $45.6 \pm 0.6$ \\
$0.12 \mathrm{Ca}(\mathrm{Ca}$-prop. $)$ & $71.9 \pm 3.6$ & $220.5 \pm 8.2$ & $47.1 \pm 0.9$ & $12.0 \pm 0.2$ & $5.83 \pm 0.19$ & $70.0 \pm 0.3$ & $-1.16 \pm 0.39$ & $44.0 \pm 1.2$ \\
$0.25 \mathrm{Ca}(\mathrm{Ca}-$ prop. $)$ & $75.4 \pm 2.1$ & $227.4 \pm 12.1$ & $43.4 \pm 4.9$ & $13.0 \pm 0.5$ & $6.25 \pm 0.38$ & $69.6 \pm 0.5$ & $0.10 \pm 1.16$ & $44.2 \pm 0.3$ \\
\hline Significance & $\mathrm{NS}$ & $\mathrm{NS}$ & $\mathrm{NS}$ & $\mathrm{NS}$ & $\mathrm{NS}$ & $\mathrm{NS}$ & $\mathrm{NS}$ & $\mathrm{NS}$ \\
\hline
\end{tabular}

NS: not significant;

Data are means \pm SE of 3 replicates.

SSC, soluble solids content; TA, titratable acidity. 
Table 2. Fruit quality traits of 'Jesca' peaches treated with TG-based formulations \pm 0.25 and $0.12 \mathrm{~mol} \mathrm{~L}^{-1} \mathrm{Ca}$ supplied as $\mathrm{CaCl}_{2}$ or Ca-propionate (Ca-prop.) following 2 or 3 months cold storage at $0{ }^{\circ} \mathrm{C}$.

\begin{tabular}{|c|c|c|c|}
\hline Ca treatments & $\begin{array}{l}\text { Flesh firmness } \\
\text { (N) }\end{array}$ & $\begin{array}{c}\mathrm{SSC} \\
\left({ }^{\circ} \text { Brix }\right)\end{array}$ & $\begin{array}{c}\mathrm{TA} \\
\left(\mathrm{mg} \mathrm{L}^{-1}\right)\end{array}$ \\
\hline \multicolumn{4}{|l|}{20 November } \\
\hline Control (untreated) & $43.2 \pm 2.4^{\mathrm{a}}$ & $13.4 \pm 0.4$ & $2.79 \pm 0.21$ \\
\hline $0 \mathrm{~mol} \mathrm{~L}^{-1} \mathrm{Ca}$ (plain TG) & $50.4 \pm 0.6^{\mathrm{a}}$ & $13.4 \pm 0.7$ & $3.35 \pm 0.09$ \\
\hline $0.12 \mathrm{~mol} \mathrm{~L}^{-1} \mathrm{CaCl}_{2}$ & $45.1 \pm 3.2^{\mathrm{a}}$ & $13.3 \pm 0.4$ & $3.01 \pm 0.25$ \\
\hline $0.25 \mathrm{~mol} \mathrm{~L}^{-1} \mathrm{CaCl}_{2}$ & $30.0 \pm 3.2^{b}$ & $15.8 \pm 1.3$ & $2.77 \pm 0.40$ \\
\hline $0.12 \mathrm{~mol} \mathrm{~L}^{-1}$ Ca-prop. & $44.6 \pm 1.6^{\mathrm{a}}$ & $13.2 \pm 0.3$ & $2.73 \pm 0.18$ \\
\hline $0.25 \mathrm{~mol} \mathrm{~L}^{-1}$ Ca-prop. & $32.0 \pm 1.9^{b}$ & $12.6 \pm 0.5$ & $3.81 \pm 0.55$ \\
\hline significance & $* * *$ & NS & NS \\
\hline \multicolumn{4}{|l|}{17 December } \\
\hline Control (untreated) & $49.1 \pm 3.4^{b}$ & $17.7 \pm 1.6$ & $1.47 \pm 0.26$ \\
\hline $0 \mathrm{~mol} \mathrm{~L}^{-1} \mathrm{Ca}$ (plain TG) & $49.2 \pm 2.1^{b}$ & $14.5 \pm 0.6$ & $1.42 \pm 0.07$ \\
\hline $0.12 \mathrm{~mol} \mathrm{~L}^{-1} \mathrm{CaCl}_{2}$ & $32.9 \pm 3.0^{\mathrm{a}}$ & $12.7 \pm 0.6$ & $1.58 \pm 0.18$ \\
\hline $0.25 \mathrm{~mol} \mathrm{~L}^{-1} \mathrm{CaCl}_{2}$ & - & - & - \\
\hline $0.12 \mathrm{~mol} \mathrm{~L}^{-1}$ Ca-prop. & $35.8 \pm 3.4^{\mathrm{a}}$ & $14.0 \pm 0.5$ & $1.36 \pm 0.08$ \\
\hline $0.25 \mathrm{~mol} \mathrm{~L}^{-1}$ Ca-prop. & $34.5 \pm 3.2^{\mathrm{a}}$ & $12.1 \pm 1.4$ & $1.48 \pm 0.22$ \\
\hline significance & $* * *$ & NS & NS \\
\hline
\end{tabular}

NS: not significant; ***: significant at $P \leq 0.001$

Data are means $\pm \mathrm{SE}$ of 3 replicates.

Statistical analysis performed by Duncan's multiple range test at $\mathrm{P} \leq 0.05$ level. Within columns, means with same letter are not significantly different.

SSC, soluble solids content; TA, titratable acidity. 
Table 3. Fruit quality traits at harvest and 15 days after cold storage of 'Calrico' peaches treated with TG-based formulations $\pm 0,0.25$ or $0.12 \mathrm{~mol} \mathrm{~L}^{-1} \mathrm{Ca}$ supplied as $\mathrm{CaCl}_{2}$ or Capropionate (Ca-prop.).

\begin{tabular}{|c|c|c|c|c|c|}
\hline Treatments & $\begin{array}{c}\text { Diameter } \\
(\mathrm{mm})\end{array}$ & $\begin{array}{c}\text { Fruit weight } \\
\text { (g) }\end{array}$ & $\begin{array}{c}\text { Flesh firmness } \\
\text { (N) }\end{array}$ & $\begin{array}{c}\text { SSC } \\
\left({ }^{\circ} \text { Brix }\right)\end{array}$ & $\begin{array}{c}\text { TA } \\
\left(\mathrm{mg} \mathrm{L}^{-1}\right)\end{array}$ \\
\hline \multicolumn{6}{|l|}{ Harvest } \\
\hline Control (untreated) & $74.8 \pm 0.6$ & $209.3 \pm 4.7$ & $39.8 \pm 3.4$ & $14.3 \pm 0.1^{\mathrm{ab}}$ & $3.80 \pm 0.34$ \\
\hline $0 \mathrm{~mol} \mathrm{~L}^{-1} \mathrm{Ca}$ & $72.3 \pm 1.4$ & $194.6 \pm 7.9$ & $33.7 \pm 6.0$ & $14.7 \pm 0.3^{b}$ & $3.83 \pm 0.43$ \\
\hline $0.12 \mathrm{~mol} \mathrm{~L}^{-1} \mathrm{CaCl}_{2}$ & $73.1 \pm 1.8$ & $201.4 \pm 11.9$ & $32.8 \pm 5.2$ & $13.7 \pm 0.3^{\mathrm{a}}$ & $3.79 \pm 0.36$ \\
\hline $0.25 \mathrm{~mol} \mathrm{~L}^{-1} \mathrm{CaCl}_{2}$ & $70.8 \pm 0.8$ & $189.5 \pm 2.4$ & $21.8 \pm 4.9$ & $14.9 \pm 0.3^{b}$ & $3.11 \pm 0.45$ \\
\hline $0.12 \mathrm{~mol} \mathrm{~L}^{-1} \mathrm{Ca}$-prop. & $72.5 \pm 0.7$ & $199.0 \pm 4.5$ & $30.0 \pm 4.0$ & $15.2 \pm 0.3^{b}$ & $4.26 \pm 0.26$ \\
\hline 0.25 mol L ${ }^{-1}$ Ca-prop. & $72.8 \pm 1.6$ & $196.5 \pm 10.0$ & $32.3 \pm 2.8$ & $14.3 \pm 0.3^{b}$ & $3.80 \pm 0.24$ \\
\hline significance & NS & NS & NS & $*$ & NS \\
\hline \multicolumn{6}{|l|}{ After cold storage } \\
\hline Control (untreated) & - & - & $40.7 \pm 5.8$ & $14.5 \pm 0.5^{\mathrm{ab}}$ & $3.83 \pm 0.32$ \\
\hline $0 \mathrm{~mol} \mathrm{~L}^{-1} \mathrm{Ca}$ & - & - & $30.9 \pm 7.5$ & $14.7 \pm 0.3^{\mathrm{ab}}$ & $3.30 \pm 0.44$ \\
\hline $0.12 \mathrm{~mol} \mathrm{~L}^{-1} \mathrm{CaCl}_{2}$ & - & - & $31.2 \pm 3.5$ & $14.0 \pm 0.2^{\mathrm{a}}$ & $3.51 \pm 0.19$ \\
\hline $0.25 \mathrm{~mol} \mathrm{~L}^{-1} \mathrm{CaCl}_{2}$ & - & - & $25.6 \pm 2.7$ & $15.7 \pm 0.2^{b}$ & $2.62 \pm 0.18$ \\
\hline 0.12 mol L ${ }^{-1}$ Ca-prop. & - & - & $27.2 \pm 3.9$ & $15.6 \pm 0.5^{b}$ & $3.41 \pm 0.14$ \\
\hline 0.25 mol L ${ }^{-1}$ Ca-prop. & - & - & $29.6 \pm 4.3$ & $15.2 \pm 0.4^{\mathrm{ab}}$ & $4.00 \pm 0.31$ \\
\hline significance & & & NS & $*$ & NS \\
\hline
\end{tabular}

NS: not significant; $*$ : significant at $P \leq 0.05$.

Data are means \pm SE of 4 replicates.

Means separated by Duncan's multiple range test at level $P \leq 0.05$. Within columns and dates of analysis, means followed by same letters are not significantly different.

SSC, soluble solids content; TA, titratable acidity 
FIG. 10.08

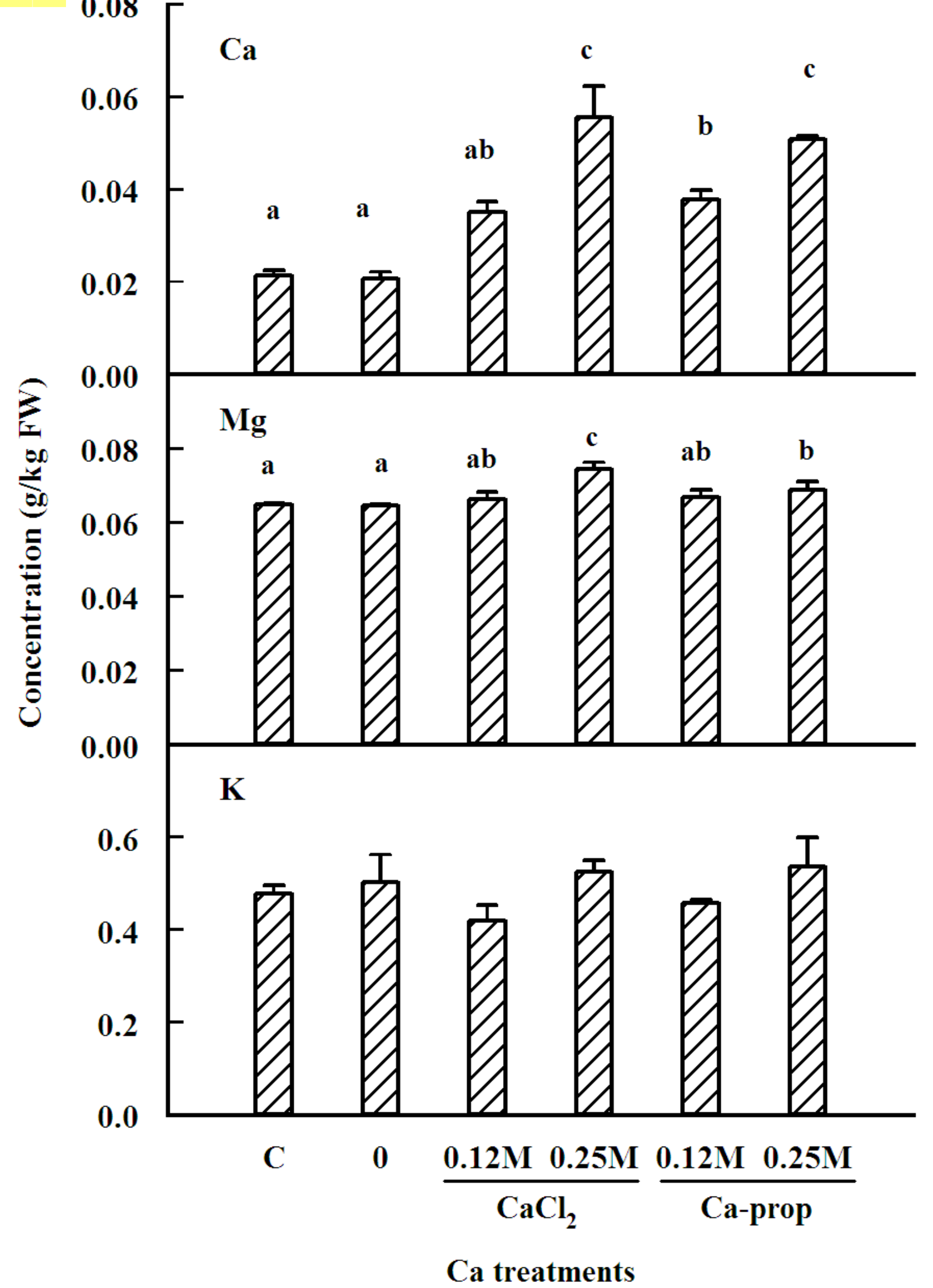


$\mathrm{Fig}$

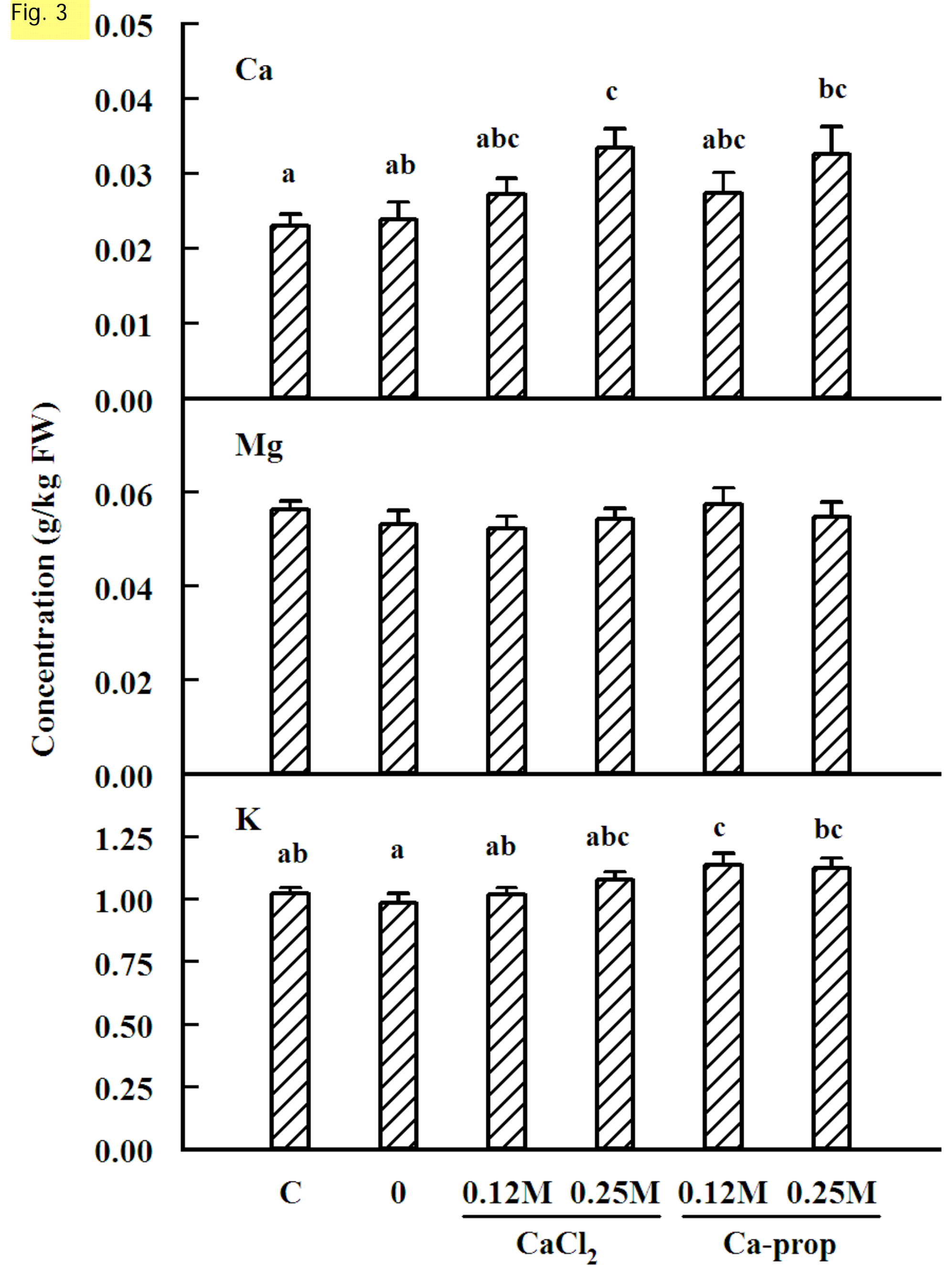

Ca treatments 
$\begin{array}{ll}\text { Fig. } 4 & 0.4\end{array}$

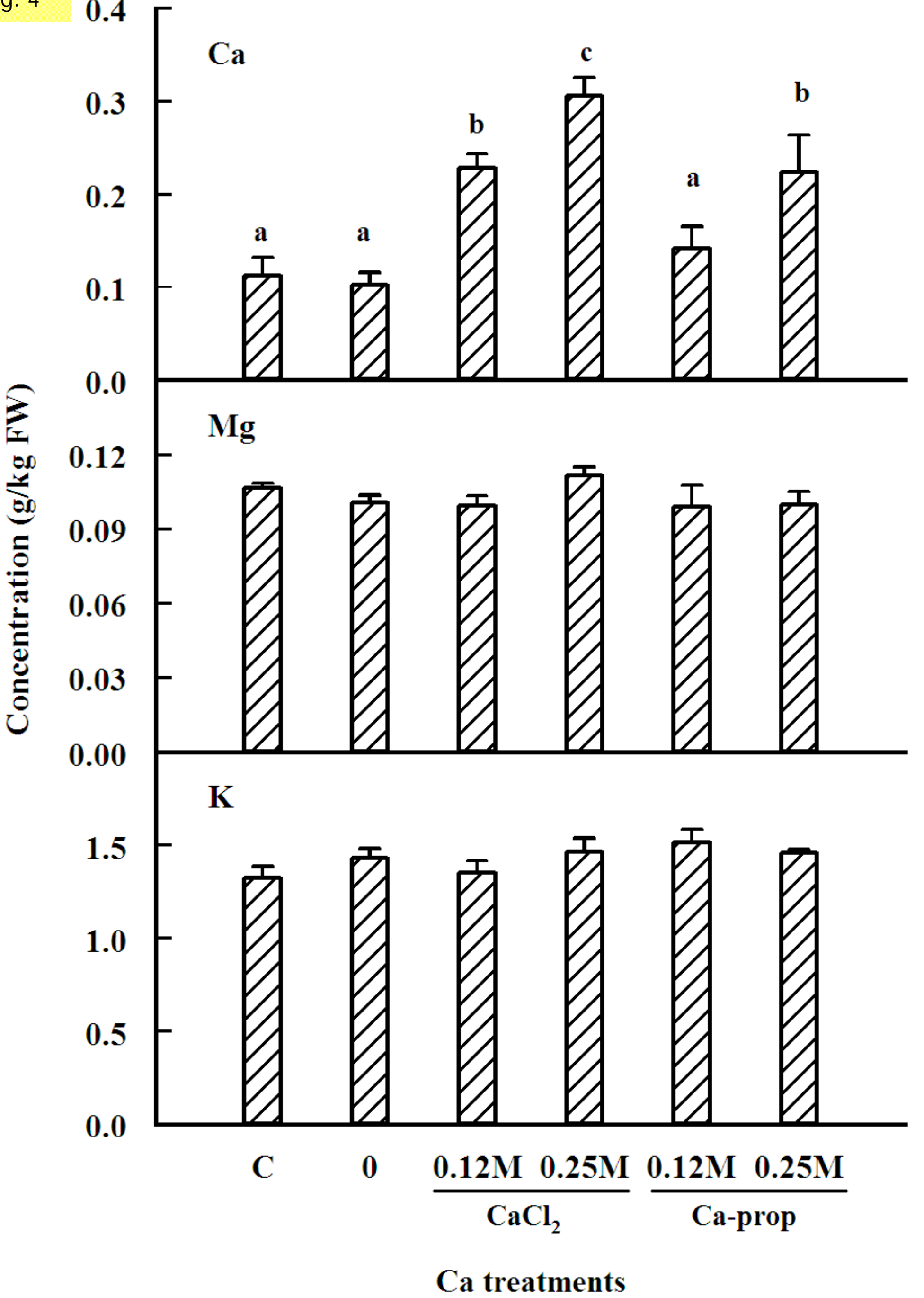




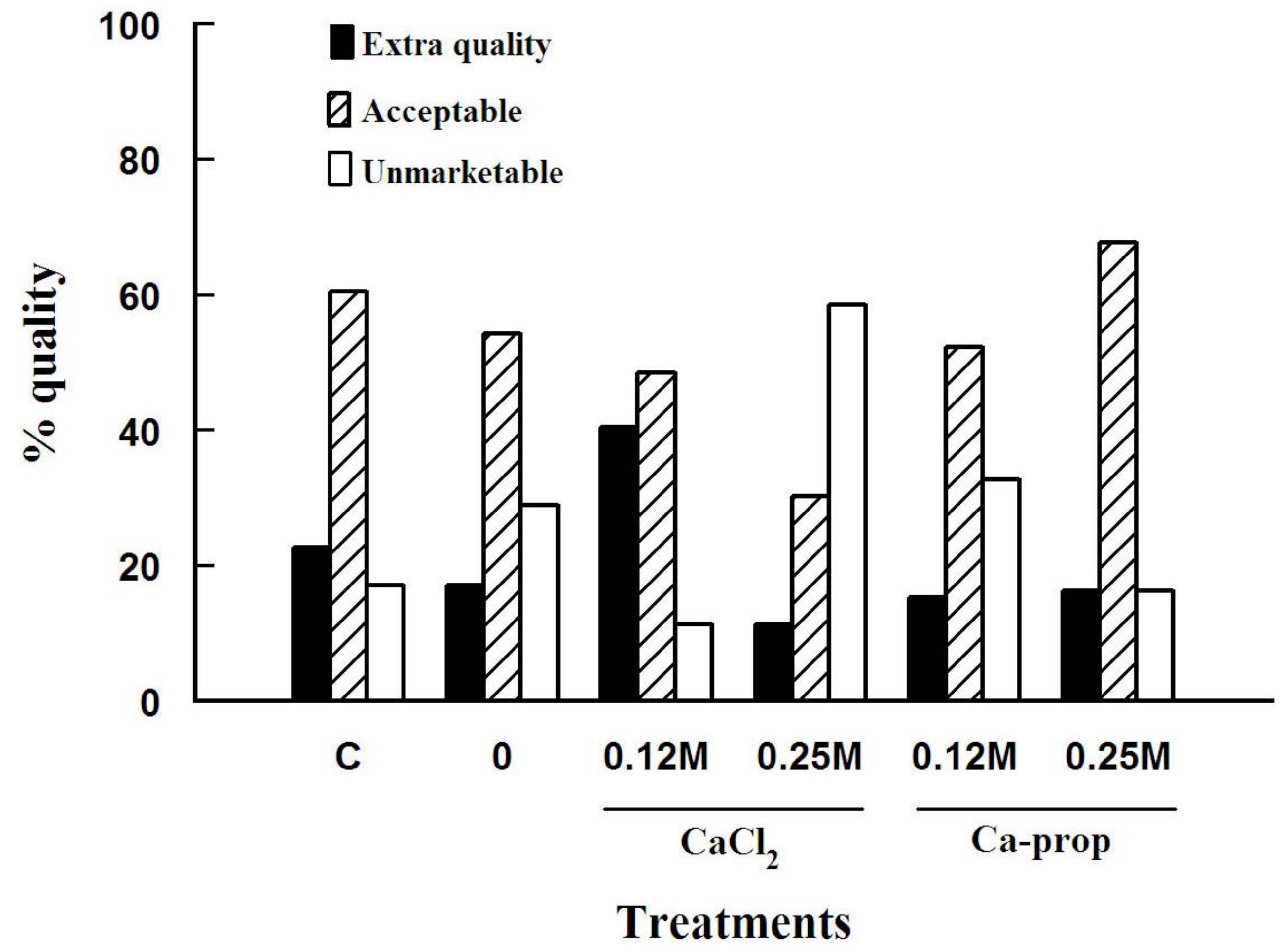




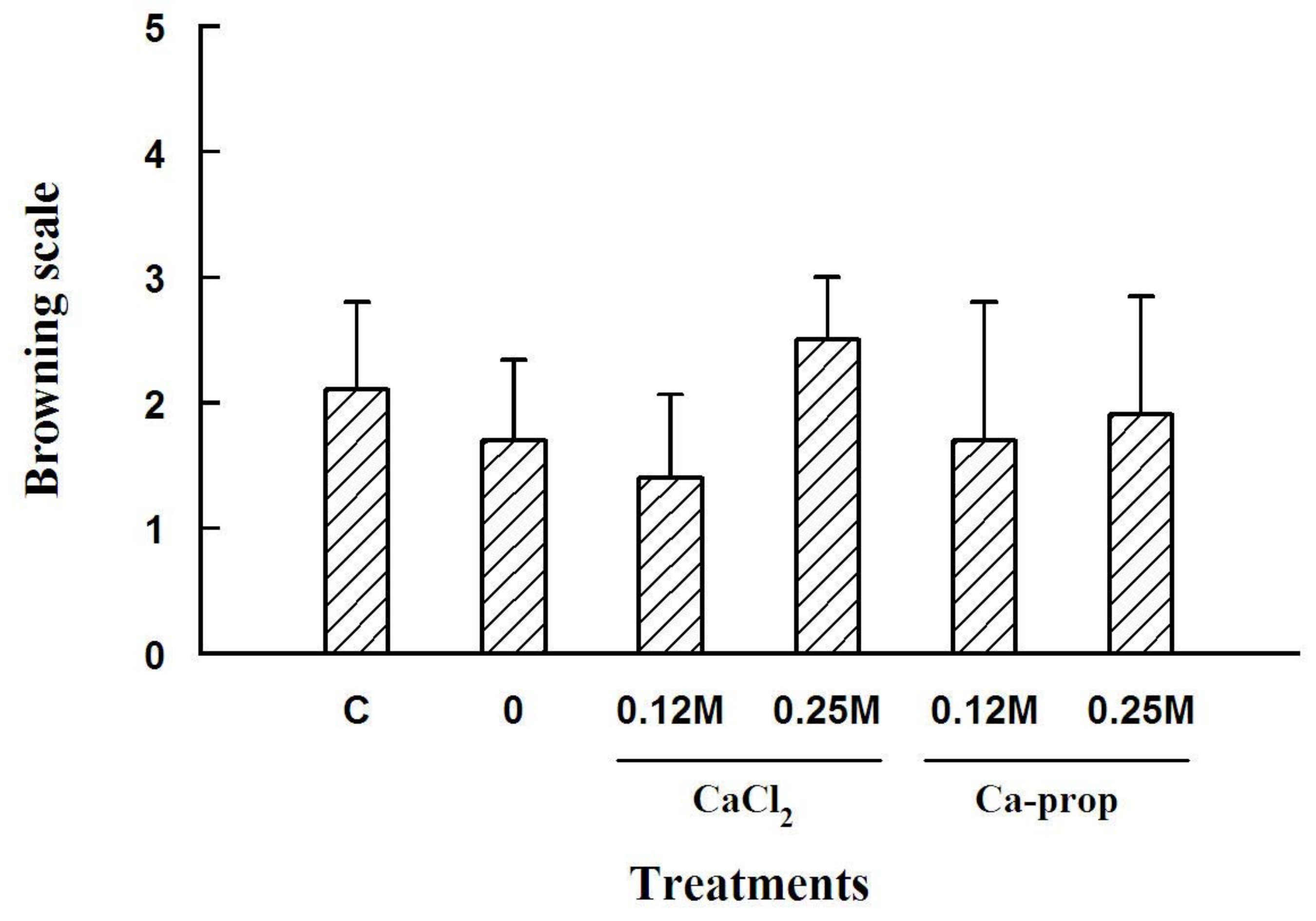


Fig. 7

A

(1)
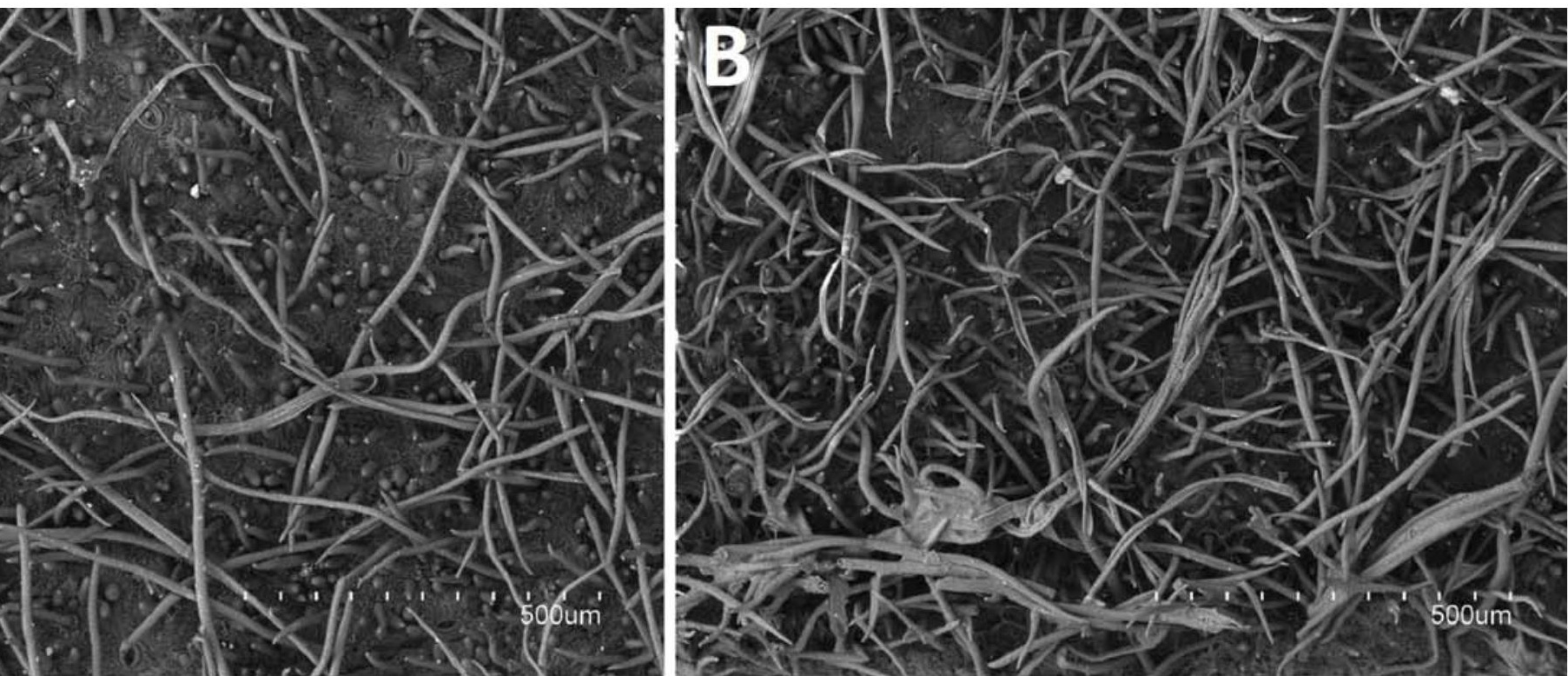

,

arsin

3are 1 -

C

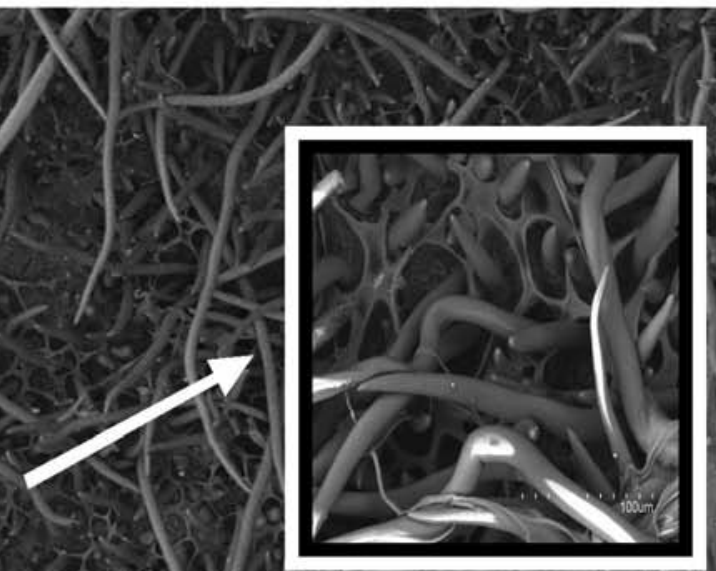

$\frac{x+3}{4}$
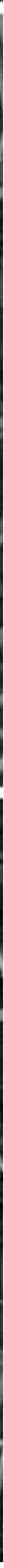